\title{
Performance Of "Natural Dermo-Resistant" Oyster Stocks-Survival, Disease, Growth, Condition And Energy Reserves
}

VG Encomio

SM Stickler

Standish K. Allen Jr.

Virginia Institute of Marine Science

FL Chu

Virginia Institute of Marine Science

Follow this and additional works at: https://scholarworks.wm.edu/vimsarticles

Part of the Marine Biology Commons

\section{Recommended Citation}

Encomio, VG; Stickler, SM; Allen, Standish K. Jr.; and Chu, FL, Performance Of "Natural Dermo-Resistant" Oyster Stocks-Survival, Disease, Growth, Condition And Energy Reserves (2005). Journal Of Shellfish Research, 24(1), 143-155.

https://scholarworks.wm.edu/vimsarticles/459 


\title{
PERFORMANCE OF “NATURAL DERMO-RESISTANT” OYSTER STOCKS-SURVIVAL, DISEASE, GROWTH, CONDITION AND ENERGY RESERVES
}

\author{
V. G. ENCOMIO, ${ }^{1,2}$ S. M. STICKLER, ${ }^{1}$ S. K. ALLEN, JR. ${ }^{1}$ AND F-L. CHU ${ }^{1 *}$ \\ ${ }^{1}$ Virginia Institute of Marine Science, 1208 Greate Road, Gloucester Point, Virginia 23062; ${ }^{2}$ Current \\ Address: Florida Gulf Coast University, 10501 FGCU Blvd. South, Modular Building \#7, Fort Myers, \\ Florida 33965
}

\begin{abstract}
To determine if natural populations of the eastern oyster possess resistance to Perkinsus marinus, progeny representing several oyster stocks from the Chesapeake Bay and the Gulf of Mexico were deployed at two sites within the Chesapeake Bay. Mortality, P. marinus infection (prevalence and intensity), shell height, condition index, and energy reserves (glycogen, protein, and lipid) were compared between these stocks. Oyster stocks from the Chesapeake Bay had higher intensities of Dermo infection than Louisiana stocks, with differences among individual stocks. Throughout the 2-y study, a natural Dermo-resistant stock from Tangier Sound (CTS), was identified. Despite infection intensities approaching those of a susceptible Rappahannock River stock (CRB) and higher than a Gulf of Mexico stock (LOB), CTS consistently had lower mortality for the 2-y grow out, and was comparable to a hatchery disease-resistant strain (XB). At a site (Port Kinsale) where the significant parasite was $P$. marinus, the LOB stock grew to the largest shell heights and had significantly lower intensities of infection. However, the performance of the LOB stock was comparatively poorer at the other deployment site (Regent Point) where MSX was present. Shell heights were highest overall in the CRB stock at Regent Point, despite high susceptibility to disease. Condition index varied between stocks, although not necessarily along trends of disease resistance since condition was highest in the CRB and XB stocks. Variations in energy reserves were strongly influenced by season, but not disease, or stock origin. The present study shows that differences between stocks contain an underlying genetic component. Differences seen between deployed stocks in mortality, growth, and condition have strong implications for development of selective criteria for an aquaculture-based industry.
\end{abstract}

KEY WORDS: Crassostrea virginica, Perkinsus marinus, Dermo, disease resistance, condition index, energy reserves, oyster

\section{INTRODUCTION}

Diseases caused by 2 protozoan pathogens, Perkinsus marinus (Dermo) and Haplosporidium nelsoni (MSX) have devastated oyster populations along the east coast of the United States, particularly the Chesapeake Bay region. Extensive annual mortalities have hampered efforts to enhance oyster populations for commercial and restoration purposes. Efforts to circumvent the effects of disease have mostly focused on selective breeding to produce more disease-resistant strains, achieving the most success with MSX resistance (Haskin \& Ford 1979, Ford \& Haskin 1987, Ford 1988). Selection for resistance to Dermo, however, has been more difficult to achieve (Ford \& Tripp 1996).

Dermo disease is chronic and disease-associated mortality does not typically occur until the second year of growth or when oysters are at or near market size $(75 \mathrm{~mm})$ (Andrews \& Hewatt 1957, Andrews \& Ray 1988). Individuals that grow beyond market size and have survived more than two seasons of exposure to P. mari$n u s$, are believed to be resistant to Dermo. However, these resistant individuals are often continually removed from most populations during commercial harvests, thus preventing long term establishment of native resistant populations (Andrews \& Ray 1988, Ray 1954, Kennedy 1996.). Some native populations, however, are suspected to possess inherent resistance or increased tolerance to P. marinus (Andrews 1954, Mackin \& Sparks 1962).

Past field studies have noted differences in resistance of translocated oyster stocks (Andrews \& Hewatt 1957). Lab experiments indicated varying resistance among eastern oyster populations from different regions supportive of natural selection for Dermo resistance (Bushek \& Allen 1996). Native populations naturally selected for Dermo resistance could provide the basis for development of more resistant strains. Until recently very few of these

*Corresponding author. E-mail: chu@ vims.edu populations have been identified in the Chesapeake Bay and none had been reported from the Gulf of Mexico (Ford \& Tripp 1996).

In 1996, Virginia oystermen discovered substantial numbers of large eastern oysters (lengths $>110 \mathrm{~mm}$ ) in Tangier Sound of the Chesapeake Bay (Blankenship 1997). Similarly, populations from the Gulf of Mexico in Louisiana (Grande Terre and Oyster Bayou) were found that were characterized by predominantly large-sized individuals in areas of high Dermo prevalence (Dr. J. Supan, Louisiana State University, pers. comm.). Because these populations possessed large and presumably long-lived $(\geq 2-3$ years) individuals in an enzootic area for Dermo, it was presumed that these populations may possess some natural Dermo resistance (Dr. J. Wesson, Virginia Marine Resources Commission, pers. comm.).

The Dermo resistance of a particular oyster strain may be a function of its ability to withstand the pathogenic effects of $P$. marinus. Secretion of proteases by $P$. marinus may be a virulence factor in causing mortality (La Peyre et al. 1995, Oliver et al. 1999). Mortality associated with disease is due to depletion of the energetic reserves of the oyster (Choi et al. 1989), resulting in impaired physiologic function and degraded condition. One of the systemic effects of diseases such as Dermo and MSX is a reduction in soft tissue growth, resulting in a decreased condition index and changes to the biochemical composition of the host (Stein \& Mackin 1957, Crosby \& Roberts 1990, Gauthier et al. 1990, Paynter \& Burreson 1991, Barber et al 1988a, Barber et al. 1988b, Newell 1985, Ford et al 1988). Changes in condition and biochemical composition may indicate differences among individuals or groups that exhibit variable response to disease stress. Few studies have examined the effects of infection by $P$. marinus on biochemical composition, particularly in relation to the progression of disease. Moreover, no study has compared condition and energy reserves among disease-resistant and susceptible oyster strains. 
To determine if there are native Dermo resistant oyster populations we collected oysters from several Chesapeake Bay and Gulf of Mexico populations. We compared disease resistance in $\mathrm{F}_{0}$ progeny from presumptive "natural Dermo-resistant" (NDR) and non-resistant populations deployed in Chesapeake Bay. We determined whether some stocks showed natural resistance to disease and whether alterations in static physiological indices reflect response to disease. To achieve these objectives, mortality, disease, growth, condition, and energy reserves among several presumptive Dermo-resistant oyster stocks were compared in a common-garden experiment at two Chesapeake Bay sites. Oysters were naturally exposed to P. marinus from September 1999 to December 2001 at these sites. Dermo resistance was defined in this study as either low prevalence or intensity of P. marinus, and/or lower diseaseassociated mortality (Valiulis 1973, Bushek \& Allen 1996). Resistant populations may maintain lower prevalences and intensities of infections, in addition to improved survival. (Gaffney \& Bushek 1996).

\section{MATERIALS AND METHODS}

\section{Stock and Site Selection}

Oysters from representative populations from the Chesapeake Bay (Tangier Sound-CTS, lower Rappahannock River-CRB, Choptank River-CCR), the Gulf of Mexico (Louisiana region) (Grande Terre-LGT, Oyster Bayou-LOB, Hackberry BayLHB) (Fig. 1A, 1B), and one disease-resistant hatchery strain (CROSBreed-XB, bred for MSX resistance 9 generations, Dermo resistance 4 generations) were spawned in the Virginia Institute of Marine Science (VIMS) oyster hatchery and reared from larval stage to settlement. Natural oyster stocks were selected for testing based on the preponderance of large-sized individuals within those populations and designated NDR, or "natural Dermo resistant" stocks (CRB, CTS, LGT, and LOB). Parents from these stocks were greater than market size (75-mm shell height), and many were larger than $100 \mathrm{~mm}$. For spawning, only individuals $>100 \mathrm{~mm}$ were collected. Susceptible stocks (CCR and LHB) were characterized by a history of low exposure to $P$. marinus. The progenies from these seven stocks were transferred to mesh bags at 3-5 mm shell height and grown in Taylor floats (Luckenbach et al. 1997). Oyster stocks were placed in separate floats containing 800 individuals per float. Two replicate floats per stock were deployed at 2 sites (Regent Point Marina-Rappahannock River and Port Kinsale-Yeocomico River, see Fig. 1A) within the Chesapeake Bay from September 1999 to December 2001. Salinity ranges for both sites were 10-16 ppt (Fig. 2). Sites were selected primarily because salinity ranges would be favorable for $P$. marinus exposure but not $H$. nelsoni. Initial surveys of wild oysters at these sites showed that MSX was not present at either site. Ease of access and availability of space were also factors in the choice of these sites.

\section{Sampling}

Sampling was conducted every 4-5 wk during each of 2 growing seasons from spring to late fall. These seasons coincide with the peak disease periods. Temperature and salinity were measured on each sampling day by thermometer and refractometer. Oysters from each float were counted to assess mortalities. Oysters from each float were randomly sampled and returned to the lab to measure shell heights, dry weights, energy reserves, and infection levels of $P$. marinus. Ten oysters were sampled for shell heights, dry
A.

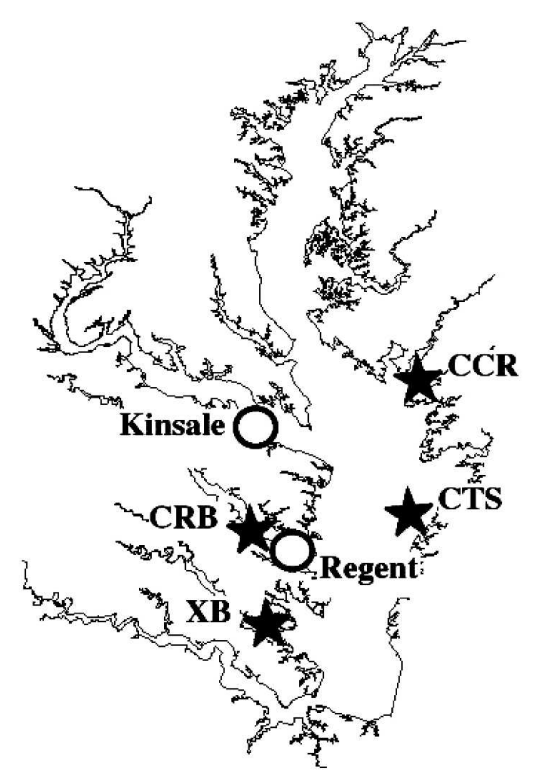

B.

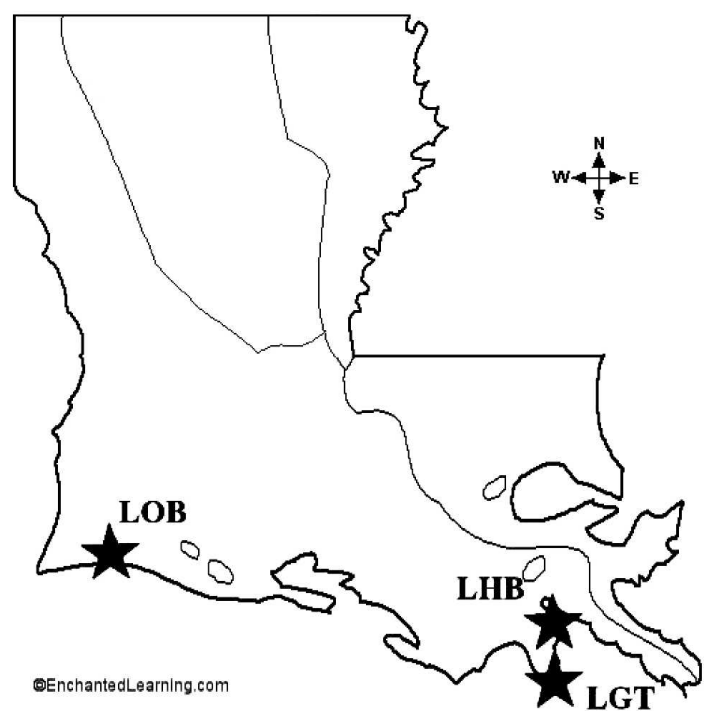

Figure 1. A. Chesapeake Bay and B. Louisiana maps showing locations of natural oyster stocks. Location of oyster stocks are indicated by a star $(\star)$. Stock acronyms are CCR $=$ Chesapeake Bay Choptank River, CRB = Chesapeake Bay Rappahannock River, CTS = Chesapeake Bay Tangier Sound, LGT = Louisiana Grande Terre, LHB = Louisiana Hackberry Bay, LOB = Louisiana Oyster Bayou. Open circles $(\bigcirc)$ indicate sites where oyster stocks were grown (Port Kinsale, Yeocomico River; Regent Point, Rappahannock River).

weights, and $P$. marinus infections. Five to 10 oysters/float were used for individual protein and glycogen measurements and 3 oysters/float were sampled for lipid analysis.

Analyses were performed on 4 stocks (CRB, CTS, LOB, and $\mathrm{XB})$. This was based on variation in survival and Dermo infection of these stocks after $1 \mathrm{y}$ of growth. As the study progressed, the CRB stock exhibited high mortalities and high P. marinus infection intensities at Regent Point in the first year (2000). We reclassified the CRB stock as disease-susceptible, despite it matching our initial criteria for an NDR stock. All Gulf oysters exhibited a similar pattern of mortality at Regent Point; therefore one stock (LOB) was selected to represent the Gulf of Mexico populations. Thus, the remaining stocks represented the range of characteristics 
A.

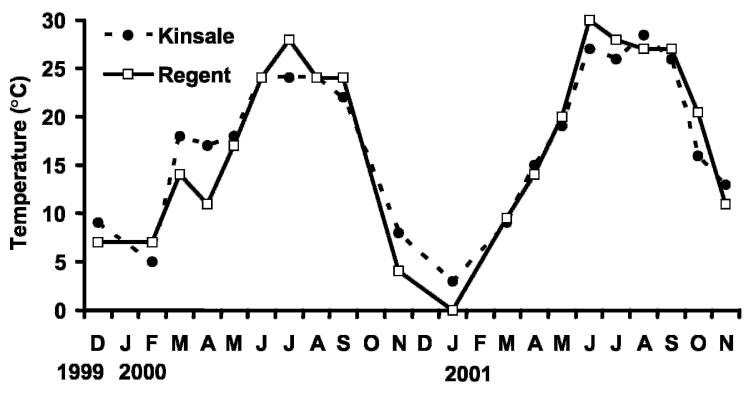

B.

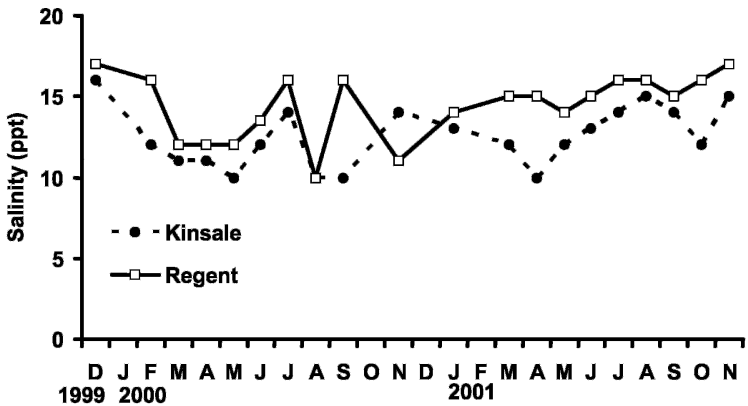

Figure 2. A. Water temperatures $\left({ }^{\circ} \mathrm{C}\right.$ ) and B. salinities (parts per thousand, or ppt) at 2 sites in the Chesapeake Bay: Port Kinsale (Yeocomico River) and Regent Point (Rappahannock River) from 1999_ 2001.

(CRB disease susceptible, Chesapeake NDR - CTS, Gulf NDR$\mathrm{LOB}, \mathrm{XB}$ ) pertinent to our general hypothesis that natural resistance to Dermo exists in distinct oyster populations.

\section{Mortality}

Live and dead oysters were counted at each sampling. Data was expressed as percent cumulative mortality [\# dead oysters at time $t$ (current period sampled) + \# total dead over previous samplings $\div$ total \# live oysters at $\mathrm{t}=0-\#$ removed for sampling). Cumulative mortalities were compared between each group at each site.

\section{Shell Height}

Shell height was measured from the anterior (shell hinge) to posterior (edge at the highest point) using vernier calipers. Shell heights were reported in $\mathrm{mm}$.

\section{Tissue Sampling}

After shell height measurement, oysters were shucked, and tissues removed. Total wet weight of oyster tissue was recorded and whole tissue was divided in two fractions. To ensure equal organ representation between tissue fractions, tissues were sectioned in half along the left and right valve axes. One fraction was used to determine the intensity of infection by $P$. marinus, and the other was used for analysis of energy reserves.

\section{Diagnosis of P. marinus (Dermo) Infection}

Prevalence and intensity of $P$. marinus infection in experimental oysters were determined using total body burden assessment (Choi et al. 1989, Nickens et al. 2002). Oyster tissues were removed from the shell. The tissue fraction used for $P$. marinus diagnosis was homogenized in $10-\mathrm{mL}$ of $0.2 \mathrm{M}$ phosphate buffer and weighed. One milliliter of tissue slurry was added to $10 \mathrm{~mL}$ alternative fluid thioglycollate medium (AFTM, Sigma Biochemicals) containing the antibiotic chloramphenicol and the anti-fungal agent nystatin. The homogenate was reweighed after tissue removal to estimate the wet weight of tissue used to assess counts of $P$. marinus. The tissue aliquot added to AFTM was incubated in the dark at room temperature for 5-7 days. Tissues were then pelleted by centrifugation, resuspended in $2 \mathrm{M} \mathrm{NaOH}$ and incubated overnight at $60^{\circ} \mathrm{C}$. Tissue pellets were washed two to three times with distilled water and resuspended in $0.1 \mathrm{M}$ phosphate buffer containing $0.2 \%$ sodium azide. Tissue suspensions were diluted if necessary, to facilitate counting and $100 \mu \mathrm{l}$-aliquots were added to a 96 well plate. One to two drops of Lugol solution (1:9 dilution) was added to each well, and $P$. marinus cells were counted using an inverted microscope. Perkinsus infection intensity was expressed as number (\#) of $P$. marinus cells/g wet tissue weight (ww). Presence or absence of $P$. marinus was used to calculate prevalence data and expressed as percentage $(\%)$ of infected oysters.

\section{Diagnosis of $\mathrm{H}$. nelsoni (MSX) Infection}

Periodically, oysters were examined histologically for $\mathrm{H}$. nelsoni infection (Burreson et al. 1988). A transverse tissue section across gill, stomach, intestine, and digestive diverticula was removed from each oyster. Tissues were fixed in Davidson solution, dehydrated, cleared, and embedded in paraffin. Sections $5-\mu \mathrm{m}$ thick, were cut, mounted on glass slides, and stained with iron hematoxylin and eosin. Intensities of infection were categorized as high, medium, or low

\section{Dry Weight and Condition Index}

Tissue fractions, except the $1.0-\mathrm{mL}$ aliquot of tissue used to diagnose $P$. marinus, were freeze dried for $48 \mathrm{~h}$ and weighed. The relationship between wet weight and dry weight of the $P$. marinus tissue fraction was calculated so as to estimate dry weight in tissue slurries added to AFTM. Total dry weights of soft tissues were measured by adding all aforementioned dry weight fractions together. Shells were dried in an oven at $60^{\circ} \mathrm{C}$ for 48 hours. Total dry weights and dry shell weights were used to calculate condition index (tissue dry weight / dry shell weight $\times 100$ ) (Walne $\&$ Mann 1975, Lucas \& Beninger 1985). This method is comparable to, but varies from the shell capacity method recommended by Crosby and Gale (1990) and is more amenable to rapid processing of numerous samples (Rainer \& Mann 1992).

\section{Energy Reserve Measurements}

\section{Glycogen Analysis}

Freeze-dried tissues were analyzed for glycogen content using the anthrone reagent method (Van Handel 1965). Tissues were homogenized in phosphate buffer (50 $\mathrm{mM}$ sodium phosphate, 1 mM EDTA and 0.5 mM PMSF, pH 7.2), digested in boiling 30\% potassium hydroxide and precipitated with $95 \%$ ethanol and saturated sodium sulfate. The glycogen precipitate was dried overnight at $60^{\circ} \mathrm{C}$. Anthrone reagent $(0.15 \%$ in $72 \%$ sulfuric acid) was added to the precipitate and incubated at $90^{\circ} \mathrm{C}$ for $20 \mathrm{~min}$ and then cooled in ice. Positive reaction with the anthrone reagent produced a blue color, directly proportional to the amount of glycogen contained within the sample. Samples were added to a 96-well microplate and read on a microplate spectrophotometer at $620 \mathrm{~nm}$. Commercially purified oyster glycogen (Sigma Biochemicals) was used to generate a standard curve for each set of microplates. Glycogen content was expressed as mg glycogen/g dry weight of tissue. 


\section{Total Protein Analysis}

Total protein concentration was determined by a modified Lowry protocol (DC BioRad assay, Lowry et al. 1951). An aliquot of the homogenate prepared for glycogen analysis was removed and diluted 1:3 in 1.0 M NaOH. Diluted samples were boiled in water for 5 min centrifuged and supernatant assayed for protein content on 96-well microplates at $690 \mathrm{~nm}$. Protein amounts were expressed in $\mathrm{mg} / \mathrm{g}$ dry weight.

\section{Lipid Analysis}

Total lipids were extracted from freeze-dried oyster tissue $(\sim 50$ mg dry weight) with chloroform: methanol: water (2:2:1) according to the procedure of Bligh and Dyer (1959). The extracted lipids were evaporated under $\mathrm{N}_{2}$ at $40^{\circ} \mathrm{C}$ and resuspended in chloroform to $10-12 \mathrm{mg} / \mathrm{mL}$ total lipid, capped under $\mathrm{N}_{2}$, and stored at $-20^{\circ} \mathrm{C}$ until analysis. Lipid contents and lipid class composition were analyzed by thin layer chromatography and flame ionization detection (TLC/FID) using an Iatroscan TH-10, MK-III analyzer (Iatron Laboratories, Japan) (Chu \& Ozkizilcik 1995). Briefly, silica coated glass rods (S-III chromarods, Iatron Laboratories Inc., Japan) were activated and cleaned by flame ionization on the Iatroscan. One micro liter of the lipid extract was then spotted on to each chromarod using a Hamilton syringe. Neutral (steryl esters, triacylglycerol, free fatty acids, and cholesterol) and polar (total phospholipid content only) lipid classes were separated on the chromarods after development in hexane:diethyl ether:formic acid (85:15:0.04). Following development, lipid contents and lipid class composition were quantified by FID on the Iatroscan. Operating conditions were $2,000 \mathrm{~mL} / \mathrm{min}$ air flow, $0.73 \mathrm{~kg} / \mathrm{cm}^{3}$ hydrogen pressure, and a scan speed of $3.1 \mathrm{~mm} / \mathrm{sec}$. Peak area integrations were performed using PeakSimple software (SRI Inc.). Peak areas corresponded to the amount of ionized lipid in each separated component. Lipid class concentrations were determined by comparison to a standard curve for each lipid class component. Lipid class standards were cholesteryl palmitate (steryl ester), triolein (triacylglycerol), oleic acid (free fatty acid), cholesterol, and phosphatidylcholine (phospholipid). Units were expressed in mg lipid/g dry tissue weight.

\section{Statistics}

Cumulative mortalities were compared by contingency table analysis (Zar 1996), using stock as row variables and live and dead numbers as column variables. Comparisons were controlled for site. Prevalence of $P$. marinus was also compared by contingency table analysis with stock as row variables and infected and uninfected as column variables. Prevalence comparisons were controlled for by date and by site. For both contingency table analyses, stock replicates were pooled.

For infection intensities, shell height, condition index, and energy reserves, oyster stocks were compared by an unreplicated repeated-measures ANOVA (Underwood 1997) with stock and sampling period as main effects. Replicate floats were nested within stock as a within subjects random factor. Analyses were separated by year (2000 and 2001) and by site. Stock differences and monthly trends were mainly uniform across both sites. Cases where there were interactions between stock and site were described qualitatively. In several comparisons, month $\mathrm{x}$ rep (stock) interactions were significant, making interpretation difficult and precluding the application of this statistical design (Underwood 1997). In those cases, variables were compared separately by month with alpha (probability of Type I error) levels adjusted by Bonferonni correction (alpha $(\alpha) / \#$ samplings: Year $2000 \alpha=$ $0.05 / 6$, Year $2001 \alpha=0.05 / 5$ ) (Underwood 1997). Application of this procedure also allowed comparisons of stocks in months where the CRB stock died, resulting in an unbalanced design. Shell height, dry weight, condition index, and energy reserves (glycogen, lipid, and protein) were analyzed separately. All variables were transformed to meet assumptions of normality and homogeneity of variance when necessary. Pair-wise comparisons from ANOVA analyses were determined by Student Newman Keul procedure. Statistical analyses were conducted using Statistical Analysis System, Version 8 (SAS Institute Inc., 1999).

\section{RESULTS}

\section{Temperature and Salinity}

Temperatures were similar at both Port Kinsale and Regent Point, and salinities were generally, although slightly, higher at Regent Point (Fig. 2A, 2B). Seasonal variation in temperature was apparent with maximum temperatures in the summer months $\left(28^{\circ} \mathrm{C}\right.$ to $\left.30^{\circ} \mathrm{C}\right)$ of both years and near freezing-to-freezing temperatures in January $2001\left(3^{\circ} \mathrm{C}\right.$ at Port Kinsale and $0^{\circ} \mathrm{C}$ at Regent Point). Salinities ranged from 10-17 ppt. Differences in salinities between the sites were most apparent in September 2000 and April 2001. During these months salinity at Regent Point was 5-6 ppt higher than Port Kinsale. Mean salinity was $\sim 2$ ppt higher at Regent Point (14.4 ppt) than at Port Kinsale (12.5 ppt).

\section{Mortality}

Significant differences in cumulative mortalities were found among stocks at each site $(P<0.0001)$. High mortalities were seen in the CRB $(53.8 \pm 3.1 \%, n=2)$ and LOB $(45.1 \pm 1.0 \%, n=2)$ stocks by November 2000 (Fig. 3). Mortality was highest in the CRB group with $100 \%$ mortality at Regent Point by July 2001 and $82.8 \pm 1.4 \%$ at Kinsale at the end of the experiment. The CTS and XB stocks showed lower (average of both sites: $46.6 \%$ and $52.6 \%$, respectively) cumulative mortalities. Mortalities were higher at Regent Point (CTS-72.4\%, XB-75.0\%) than Port Kinsale (CTS-20.2\%, XB-31.0\%). Cumulative mortalities for the LOB stock $(47.4 \%)$ were intermediate between the CRB and XB/CTS groups at Port Kinsale. High mortalities in the LOB stock at Port Kinsale, however, were observed in the March, 2001 sampling. Mortality of LOB oysters reached $100 \%$ at Regent Point, by the end of the study.

\section{Perkinsus marinus Infections}

\section{Prevalence}

Perkinsus marinus infections were detected at Regent Point in June of 2000 and at Port Kinsale in August, 2000 (Fig. 4A). Infections progressed more rapidly at Regent Point, resulting in higher prevalences compared to Port Kinsale. Prevalence at Kinsale was lower $(8.8 \pm 3.0 \%)$ in May 2001 compared to Regent Point $(70.0 \pm 10.0 \%)$, suggesting that infections may have cleared in oysters at Port Kinsale during the overwintering period. The prevalence remained high at Regent Point during May 2001, indicating that oysters were exposed to $P$. marinus earlier and at higher levels than at Port Kinsale. Significant variation in prevalence between stocks occurred from 2000 to June 2001 (Fig. 4B, 4C). Within each month, prevalence fluctuated between stocks. 

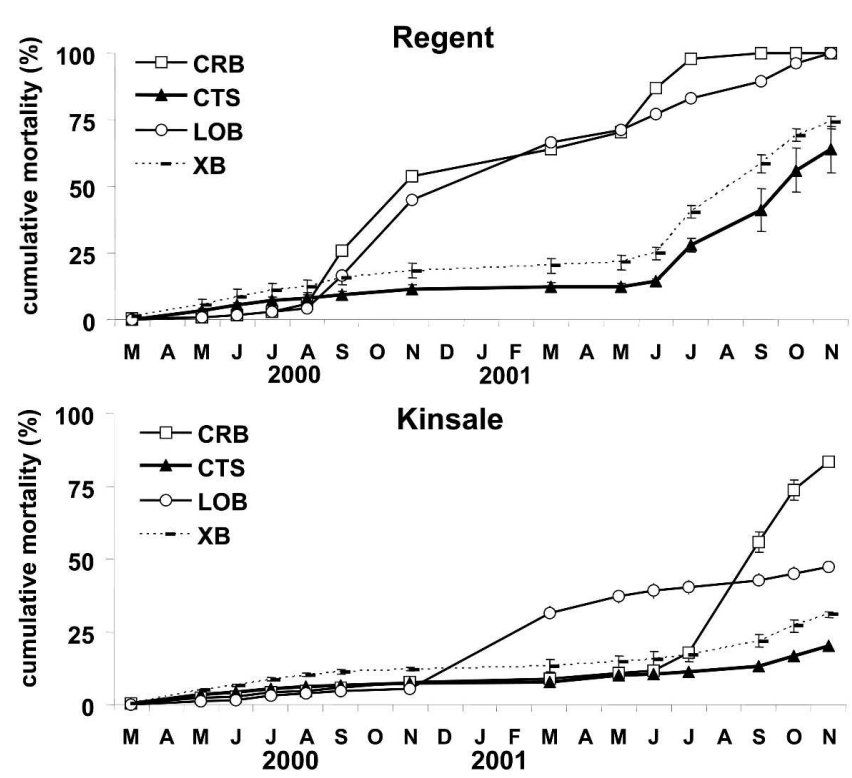

Figure 3. Cumulative mortality $(\%)$ data of three native oyster stocks and one hatchery disease-resistant strain at A. Port Kinsale and B. Regent Point. CRB = Chesapeake Bay, Rappahannock River, CTS = Chesapeake Bay, Tangier Sound, LOB = Louisiana, Oyster Bayou, $\mathrm{XB}$ = CROSBreed strain. Data was collected every 4-5 wk in 2 seasonal periods (May to November 2000 and May to November 2001). Sampling is not continuous between November 2000 and May 2001. Data are presented as mean percentage $(\%)$ mortality \pm standard error of the mean (SEM) $n=2$ replicate floats per stock.

Despite inter-stock variation in prevalence, across months and sites there remained a significant effect of stock on prevalence $(P=$ $0.0002)$. Prevalence was lower in LOB and CTS stocks $(70.0 \%$ and $74.8 \%$ ), whereas prevalences in $\mathrm{CRB}$ and $\mathrm{XB}$ stocks were higher ( $88.8 \%$ and $81.9 \%$, respectively). By July 2001, prevalences were at or near $100 \%$ for all stocks through the remaining sampling periods.

\section{Infection Intensities}

Stocks were compared for differences in intensities of infection (\# of P. marinus cells/g ww) by month for each site. In 2000, Perkinsus infections varied significantly by month $(P<0.0001)$ at both sites. At Port Kinsale, intensities showed no significant effects between stocks. Differences between stocks were most apparent at Regent Point. Mean intensities for all stocks were $8.4 \times$ $10^{6} \pm 8.3 \times 10^{6}$ cells/g ww at Regent Point and $1.2 \times 10^{3} \pm 1.0 \times$ $10^{3}$ cells/g ww at Port Kinsale. Because of significant interactions between replicates and months at Regent Point, data were analyzed separately by month. Nevertheless, differences in infection between stocks were apparent and significant starting in June 2000 $(P<0.01)$, as overall mean infection levels were low $(87.0 \pm 0.6$ cells/g ww) and fluctuated from June to August 2000. By November 2000, infections at Regent Point were highest in the CRB stock $\left(1.8 \times 10^{7} \pm 2.1\right.$ cells/g ww $)(P<0.01)$. The CTS and LOB stocks had intermediate mean intensities and the XB oysters had the lowest intensities of $P$. marinus (Fig. 5). At both sites and across all stocks, $P$. marinus infections increased over time and were highest at Regent Point. Intensity decreased from Nov 2000 to May 2001.

From May to October 2001, intensities increased (Fig. 5) coincident with increased mortalities (Fig. 3). Significant month by
A.

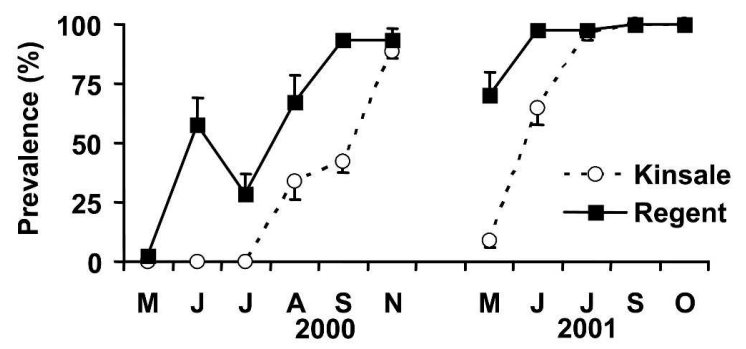

B.
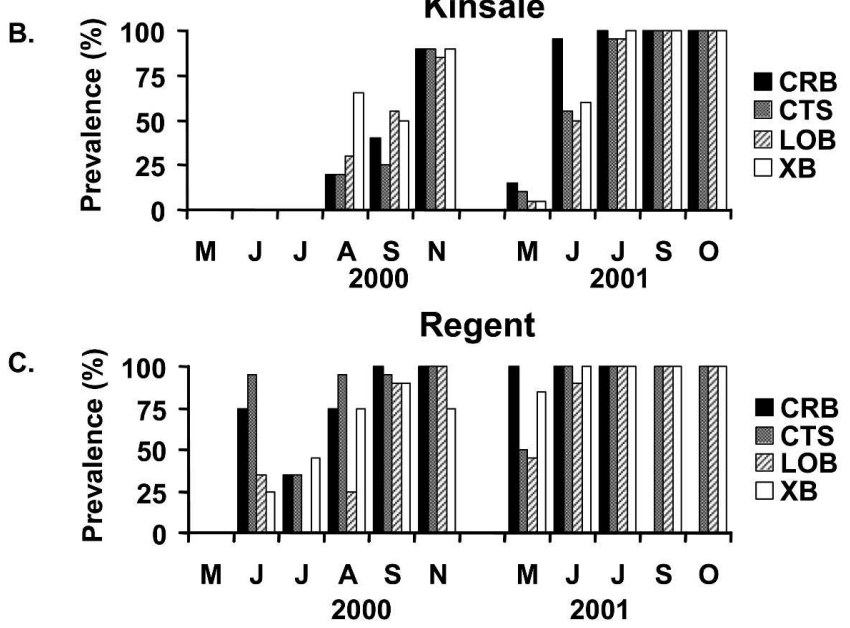

Figure 4. Prevalences of Perkinsus marinus at Port Kinsale and Regent Point from 2000 to 2001. Prevalence is percentage (\%) of infected oysters. Data presented in the top figure (A.) are mean prevalence \pm SEM. ( $n=4$ oyster stocks [20 oysters/stock] for each site). Prevalences of individual stocks (CRB, CTS, LOB, and XB) at each site (B. and C.) are shown separately. Prevalences of each stock are collapsed across two replicate floats/stock. At Regent Point, prevalence data for the CRB stock from September to October 2001 is absent due to $100 \%$ mortality in that stock. Note that data are presented for each month sampled. CRB = Chesapeake Bay, Rappahannock River, CTS = Chesapeake Bay, Tangier Sound, LOB = Louisiana, Oyster Bayou, $\mathrm{XB}=$ CROSBreed strain.

stock interactions reflected high variability in infections among replicate floats at both Kinsale and Regent. Despite this, there were significant differences in infection levels among stocks. Consistent with the previous year, the CRB stock had the highest infections and was significantly higher than the other stocks at Regent Point, before reaching 100\% mortality by May to July 2001 (Fig. 3). At Port Kinsale, LOB infections remained below $1.0 \times 10^{6}$ cells $/ \mathrm{g}$ ww throughout October, with maximum infections reaching $5.0 \times 10^{5}$ cells/g ww. Infection levels in the LOB stock were significantly lower at both Kinsale and Regent. Overall, infections at Regent were higher than at Kinsale, and mortality increased as infections reached or exceeded $1.0 \times 10^{6}$ cells/g ww at both sites. By October 2001 all oysters at Regent Point had infections above $1.0 \times 10^{7}$ cells/g ww.

\section{MSX Infections}

At Regent Point, oysters examined between July and November 2000 showed presence of Haplosporidium nelsoni. At Regent Point in 2001, MSX was detected in 48/124 animals examined in May, July, and October. No significant differences between stocks were observed, but MSX was not detected in any XB oysters 

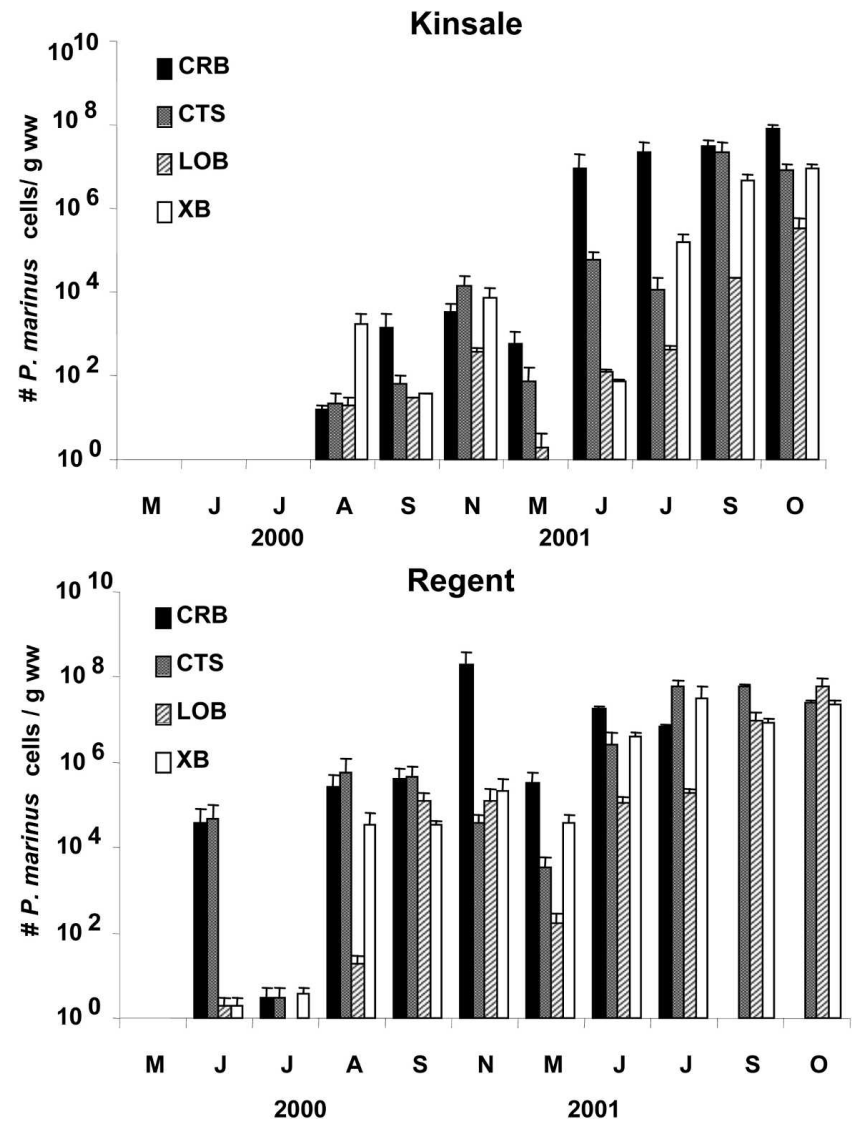

Figure 5. Infection intensities of CRB, CTS, LOB, and XB oysters at A. Port Kinsale and B. Regent Point from 2000 to 2001. Data are presented as mean number (\#) of $P$. marinus cells (enlarged hypnospores $) / g$ wet weight $(w w) \pm$ SEM. $(n=2$ replicates of 10 animals for each stock). Numbers of $P$. marinus cells/g ww are graphed on a logarithmic scale. Note break in sampling periods between November 2000 and May 2001. CRB = Chesapeake Bay, Rappahannock River, CTS = Chesapeake Bay, Tangier Sound, LOB = Louisiana, Oyster Bayou, XB $=$ CROSBreed strain.

examined. Haplosporidium nelsoni was not detected at Port Kinsale in 129 animals examined.

\section{Shell Heights}

In 2000, shell heights increased over time and were significantly different between stocks $(P<0.0001)$. Comparisons between stocks showed that CRB grew significantly more than CTS, LOB, and XB stocks at both sites (Fig. 6). At Port Kinsale, the CTS stocks had significantly lower shell heights than the other three stocks, whereas the LOB and XB stocks were not significantly different. Shell heights were larger at Regent Point than at Port Kinsale. Interactive effects were significant as well, but as with $P$. marinus infections, overall trends in shell height across stock, site, and month were consistent.

In 2001, increases in shell height over time and among stocks were significant at Port Kinsale $(P<0.0001)$. At Port Kinsale, the $\mathrm{CRB}$ and LOB stocks grew to the largest average shell heights. Final shell heights measured in October 2001 were CRB: $88.1 \pm$ $0.2 \mathrm{~mm}$, LOB: $95.8 \pm 1.4 \mathrm{~mm}$ (mean \pm standard error of the mean, or SEM, $n=20$ oysters from each stock). The CTS and XB shell heights were lower $(76.4 \pm 0.5 \mathrm{~mm}$ and $79.3 \pm 0.7 \mathrm{~mm})$. From May
A.

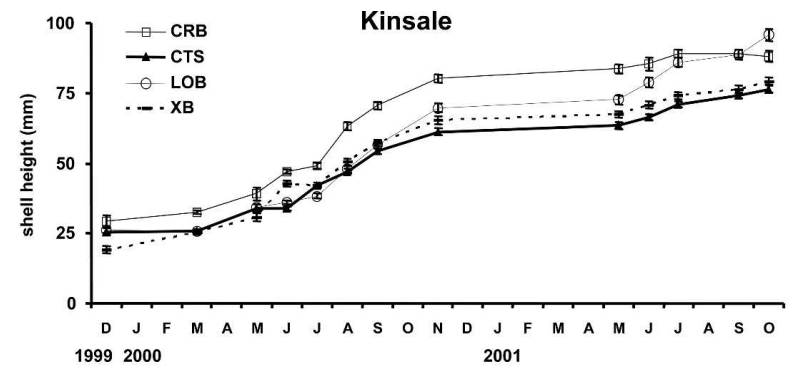

B.

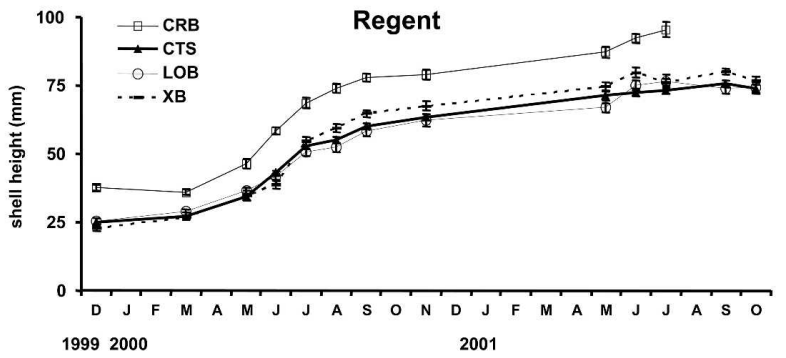

Figure 6. Comparisons of shell heights among CRB, CTS, LOB, and XB oysters at A. Port Kinsale and B. Regent Point during periods (shown as months) sampled in 2000 to 2001. Data are mean shell heights $(\mathrm{mm}) \pm \operatorname{SEM}(n=\mathbf{2}$ replicates of 10 oysters for each stock). CRB = Chesapeake Bay, Rappahannock River, CTS = Chesapeake Bay, Tangier Sound, LOB = Louisiana, Oyster Bayou, XB = CROSBreed strain.

to July, shell heights at Regent Point were significantly different between stocks $(P<0.0001)$. At Regent Point the CRB stock grew to the largest sizes but reached $100 \%$ mortality by July 2001 . Shell heights at Regent Point were similar among the CTS, LOB, and $\mathrm{XB}$ stocks $(73.9 \pm 0.8,74.3 \pm 1.3,76.8 \pm 2.7 \mathrm{~mm}$, respectively) from May to July. During September to October, XB oysters grew to significantly greater sizes $(P=0.0053$ for main effects of stock only) than the LOB group. The LOB shell heights were the lowest at Regent Point, but highest at Port Kinsale, indicating an interactive effect of site on this stock. Within the other stocks, shell heights were greater at Regent Point than at Port Kinsale.

\section{Dry Weights}

Dry weights varied significantly among stocks and months at both sites $(P<0.0001)$ in 2000. Dry weight differences among stocks reflected differences in shell height $(\mathrm{CRB}>\mathrm{LOB}, \mathrm{XB}>$ CTS). Increases in dry weight were highest from September to November sampling dates, particularly in the CTS, LOB, and XB stocks (Fig. 7). Differences in dry weight among stocks showed consistent trends from month to month, although stock $\mathrm{x}$ month effects were significant $(P<0.0001)$. At Regent Point, the CTS stock grew rapidly from September to November and had the highest dry weights compared to the other stocks. At both sites, growth was greatest during the fall with dry weights increasing from September to November by 1.5 and 2.0 times at Regent Point and Port Kinsale.

Tissue dry weights in 2001 were characterized by a sharp decrease in June from peak dry weights in May (Fig. 7) and no longer reflected changes in shell height. Significant differences between stocks were seen at both sites. At Port Kinsale, dry weights were highest in the LOB stock. At Regent Point, differences among stocks were similar to 2000, with the CRB stock having the highest dry weights from May to July, although the CRB stock did not 
A

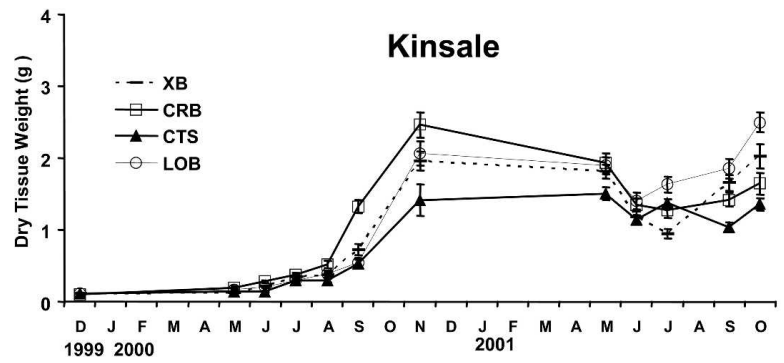

B

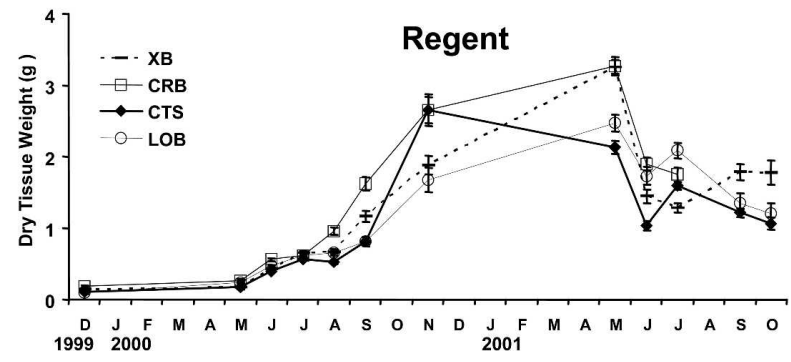

Figure 7. Dry tissue weight measurements of CRB,CTS, LOB, and XB oysters at A. Port Kinsale and B. Regent Point during periods (shown as months) sampled in 2000 to 2001. Data are mean dry weights $(\mathrm{g}) \pm$ SEM ( $n=2$ replicates, 10 oysters/replicate/stock). CRB = Chesapeake Bay, Rappahannock River, CTS = Chesapeake Bay, Tangier Sound, LOB = Louisiana, Oyster Bayou, XB = CROSBreed strain.

differ significantly from the LOB and XB stocks. The CTS stocks had the lowest dry weights in the fall. As in the previous year, dry weights were higher at Regent Point than at Port Kinsale. This was uniform across all stocks except for the LOB stock, which had lower dry weights at Regent Point than at Port Kinsale.

\section{Condition Index}

In 2000, condition index (CI) varied significantly between stocks and months $(P<0.0001)$, and reflected changes in dry weight. Condition index decreased from May to July and increased in all stocks at both sites from September to November (Fig. 8). Condition index increased from the fall to winter, coinciding with an accumulation of glycogen and triacylglycerol (TAG) (see following sections).

In 2001 the highest condition index was during the May sampling with decreases in the subsequent month. Variation among stocks in condition index was consistent with the previous year, the $\mathrm{XB}$ strain maintained the highest condition over the other stocks at both sites $(P<0.0001)$. At Regent Point, changes in LOB condition reflected changes in shell height and dry weight. Prior to $100 \%$ mortality, CRB oysters also had a significantly higher condition index than CTS and LOB stocks at both sites.

\section{Glycogen}

Glycogen content varied seasonally, although not significantly, with maximum values seen during the winter-spring periods (Fig. 9). Decreases in glycogen occurred during the summer months. Patterns in glycogen content were consistent across both sites. No significant differences, however were noted due to month, stock, or site.

\section{Protein}

Protein content did not vary by stock but seasonal variation was seen with minimum levels observed in the fall (Fig. 10). Changes
A.

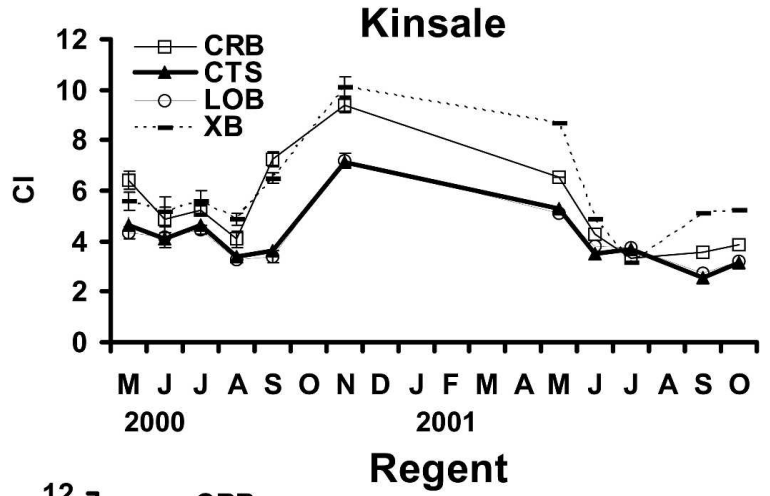

B.

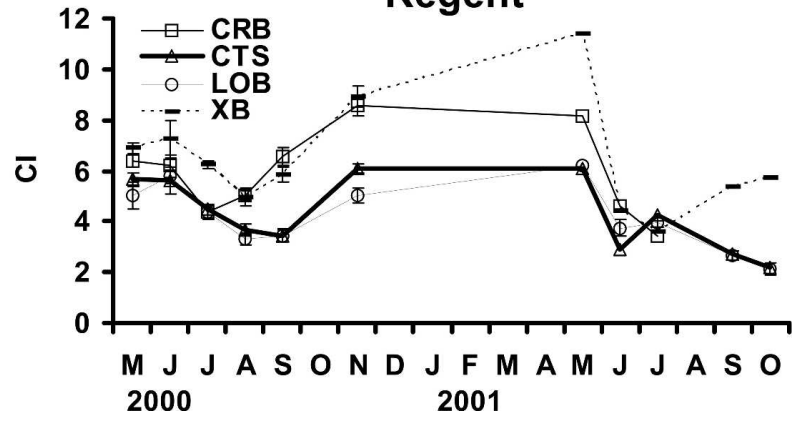

Figure 8. Condition index (CI) values of CRB, CTS, LOB, and XB oysters at A. Port Kinsale and B. Regent Point during periods (shown as months) sampled in 2000 to 2001. Condition index was measured according to Lucas and Beninger (1985) as (dry tissue weight/dry shell weight $) \times 100$. Data are presented as mean CI \pm SEM $(n=2$ replicates of 10 oysters/rep/stock). CRB = Chesapeake Bay, Rappahannock River, CTS = Chesapeake Bay, Tangier Sound, LOB = Louisiana, Oyster Bayou, XB = CROSBreed strain.

in weight-specific protein amounts (mg/g dry weight) decreased during periods of increased glycogen.

\section{Lipid}

Lipid class composition (steryl esters, triacylglycerol, free fatty acids, cholesterol, and phospholipids) was compared among oyster stocks in August and November 2000 and May to July and September-October, 2001 (Fig. 11). Significant differences were found in triacylglycerol (TAG) content due to month and stock. Interaction between month and stock were significant at Port Kinsale but not at Regent Point. Seasonal variation in TAG was most apparent at Kinsale, with an increase in TAG in all stocks except the CRB stock, between November 2000 and May 2001 (Fig. 11A). At both sites TAG decreased in June and July 2001 (Fig. $11 \mathrm{~A}$ and 11B). TAG levels were highest in LOB and CRB stocks at both sites.

\section{DISCUSSION}

\section{Natural Dermo Resistance}

Our results showed that one native stock (CTS) possesses resistance to Dermo disease, comparable to that of a hatchery strain (XB) selected for resistance to Dermo and MSX. Performance of this stock supported the assumption that individuals from this population was Dermo-resistant and that resistance may be genetically based. Furthermore, we have tested the $\mathrm{F}_{1}$ progeny of the $\mathrm{F}_{0}$ CTS stock. The performance (growth, condition, $P$. marinus infection, and survival of the F1 CTS oysters was similar to the F0 
A.

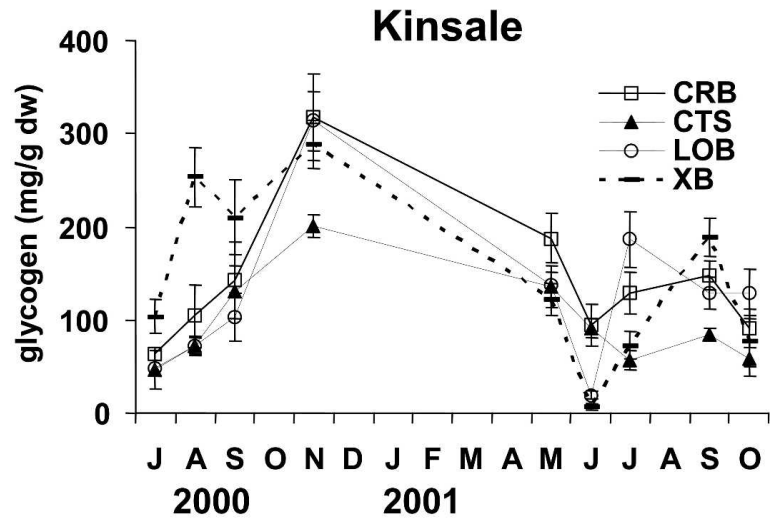

B.

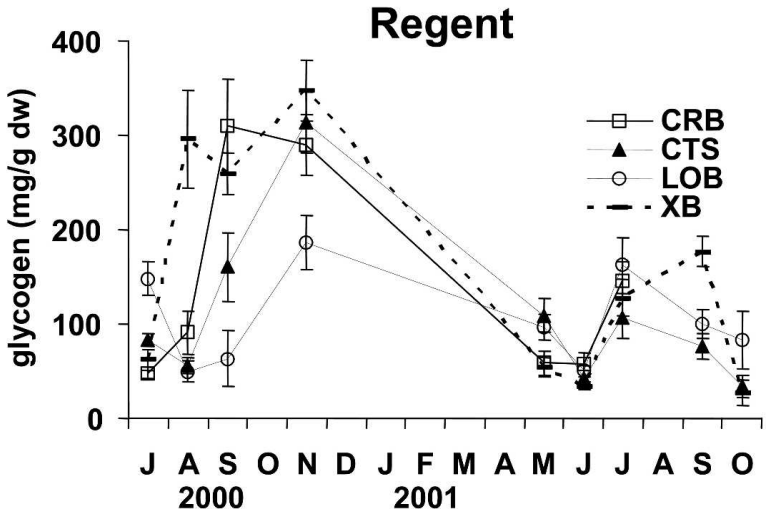

Figure 9. Glycogen contents of CRB, CTS, LOB, and XB oysters at A. Port Kinsale and B. Regent Point during periods (shown as months) sampled in 2000 to 2001. Data presented are mean glycogen (mg/g dry weight, or DW) \pm SEM $n=2$ replicates of 6-10 oysters per replicate per stock. CRB = Chesapeake Bay, Rappahannock River, CTS = Chesapeake Bay, Tangier Sound, LOB = Louisiana, Oyster Bayou, XB = CROSBreed strain.

stock tested in the present study (Encomio 2004, Encomio \& Chu 2005).

Dermo disease is generally characterized as causing mortality in oysters in their second year of growth, as they approach or attain market size and accumulate $P$. marinus to a critical infection level (Burreson 1991, Paynter \& Burreson 1991), generally at $10^{6}$ cells/g ww (Choi et al. 1989, Bushek et al. 1994). The CTS and XB oysters were at or near market size (75-mm shell height) and had infections exceeding critical infection levels of $1.0 \times 10^{6}$ cells $/ \mathrm{g}$ ww, when mortalities began to increase. Cumulative mortalities in the CTS and XB groups, however, remained lower than the CRB stock, despite comparable infection levels. Because mortalities did increase rapidly in those stocks at $1.0 \times 10^{6}$ cells/g ww, mortality was delayed, implying an ability to resist infections for longer periods. Delayed mortality in disease-resistant oysters was also demonstrated in strains of $O$. edulis exposed to Bonamia ostreae, a protistan parasite that causes mortality after chronic infection, a similar characteristic of Dermo disease (Naciri-Graven et al. 1998). Stock differences in survival, growth, and condition were consistent between grow-out sites, further suggesting a genetic basis for their differences.

It is not certain whether the LOB stock was Dermo-resistant. Cumulative mortalities of the LOB stock were higher than the XB and CTS groups at both sites, particularly at Regent Point. However, although LOB cumulative mortality was higher than the CTS or $\mathrm{XB}$, at Kinsale most of that mortality was attributed to deaths
A.

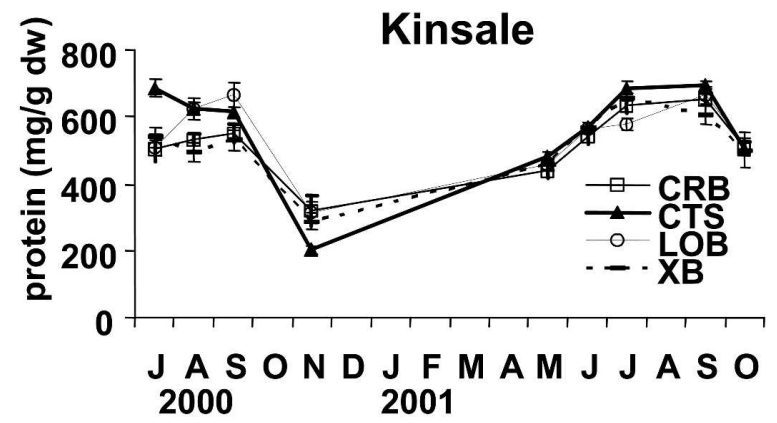

B.

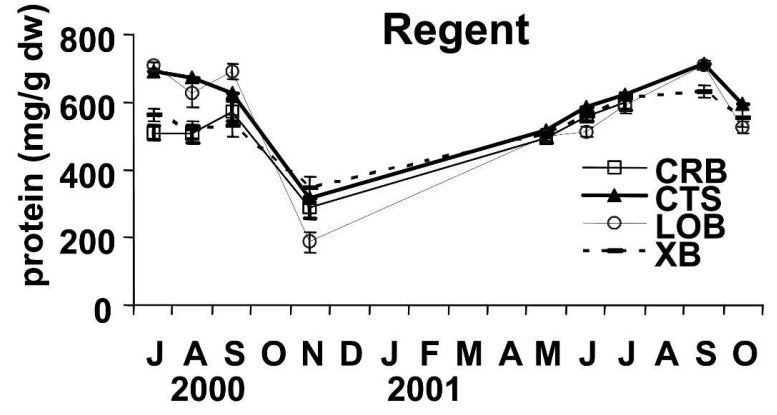

Figure 10. Comparisons of protein contents among CRB, CTS, LOB, and XB oysters at A. Port Kinsale and B. Regent Point during periods (shown as months) sampled in 2000 to 2001. Data presented are mean protein $(\mathrm{mg} / \mathrm{g}$ dry weight, or DW) $\pm \mathrm{SEM}, n=2$ replicates of 6-10 oysters each. CRB = Chesapeake Bay, Rappahannock River, CTS = Chesapeake Bay, Tangier Sound, LOB = Louisiana, Oyster Bayou, $\mathrm{XB}=$ CROSBreed strain.

that occurred just prior to the March, 2001 sampling. This mortality event was believed to have been caused by exposure to freezing temperatures during extreme low tides that occurred during the weeks before sampling. Mortality only occurred in the exposed floats that contained Louisiana oysters. Chesapeake and XB floats that were similarly exposed did not contain noticeable mortalities. After this mortality event, monthly mortality rates were low in the LOB stock and lower than all other groups. At Regent Point, where LOB mortalities were very high, MSX disease may have been a contributing factor to those high mortalities (see following section). Additionally, at Port Kinsale, LOB oysters grew beyond market size $(>100 \mathrm{~mm})$, had lower levels of infection, and lower mortality rates during the period of $P$. marinus exposure. At Port Kinsale, mean intensities of $P$. marinus infection in the LOB stock remained below critical infection levels of $10^{6}$ cells/g ww for the entire study. At Regent Point, infection intensities of the LOB stock remained at sublethal levels until September 2001. Furthermore, LOB oysters from the same cohort as described in this study, had higher survival, grew to greater sizes, and had lower intensities of P. marinus than the CRB, CTS, and $\mathrm{XB}$ groups in grow-out comparisons conducted concurrently in Louisiana (Stickler 2004). These observations, particularly the performance of the LOB oysters at Port Kinsale, suggest that the LOB stock could be a potential candidate for Dermo resistance. However, further tests of Louisiana stocks must be performed to determine whether Dermo resistance in these stocks is geographically broad, as demonstrated in Gulf stocks by Bushek and Allen (1996), and not site-specific.

Previous studies have shown that disease resistance among eastern oysters contains a genetic component (Haskin \& Ford 1979, Burreson 1991, Bushek \& Allen 1996). Bushek and Allen 


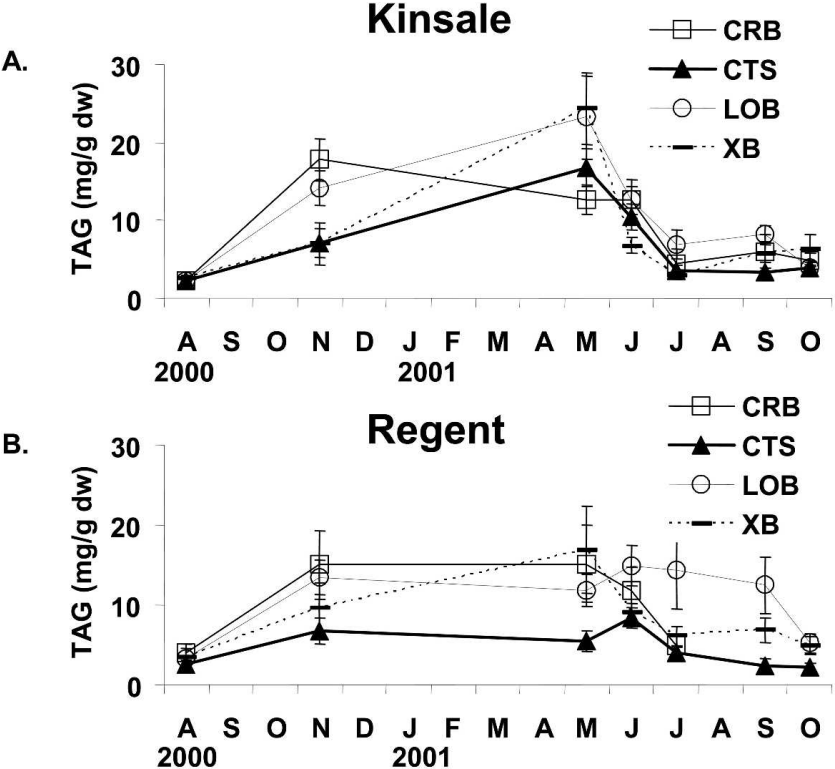

Figure 11. Triacylglycerol (TAG) contents in CRB, CTS, LOB, and XB oysters at A. Port Kinsale and B. Regent Point during periods (shown as months) sampled in 2000 to 2001. Mean TAG (mg/g dry weight, or DW) \pm SEM $n=2$ replicates of 3-8 oysters/replicate per stock are presented. CRB $=$ Chesapeake Bay, Rappahannock River, CTS = Chesapeake Bay, Tangier Sound, LOB = Louisiana, Oyster Bayou, XB = CROSBreed strain.

(1996) found that Gulf of Mexico oysters were uniformly resistant to a range of geographic strains of $P$. marinus, but these relationships were not tested in the field. Field comparisons have shown variation in survival between groups of oysters (Andrews \& Hewatt 1957, Burreson 1991, Ragone-Calvo et al. 2003) exposed to Dermo. Those studies differed from the present study in several ways. Andrews and Hewatt (1957) compared mortalities in translocated oysters, rather than stocks spawned and reared under identical conditions. Burreson (1991) examined differences between native stocks similarly to our study but primarily focused on comparisons with MSX resistant strains and response to Dermo and MSX. Further, stocks were deployed in disease enzootic sites at different ages, making stock comparisons difficult.

Ragone-Calvo et al. (2003) examined a Delaware Bay strain (DEBY) that exhibited improved resistance to Dermo and MSX over successive generations. Comparisons with native stocks $\left(\mathrm{F}_{0}\right.$ Tangier Sound and Mobjack Bay) showed superior survival in the DEBY strain. The $\mathrm{F}_{\mathrm{O}}$ Tangier Sound stock used in their comparisons experienced high mortalities $(-80 \%)$ in high salinity environments (15-25 ppt during periods of high Dermo prevalence). In contrast, the Tangier Sound stock used in our study survived better than an XB strain bred for multiple generations (9 MSX, 4 Dermo) for disease resistance in two moderate salinity environments (8-15 ppt). Clearly, the Tangier Sound population requires further examination, particularly with regards to genotype-environment interactions. However, comparisons of the $\mathrm{F}_{0} \mathrm{CTS}$ and CRB oysters indeed demonstrate intra-regional variability in Dermo resistance between Chesapeake Bay stocks.

\section{Site Variation in Disease Dynamics}

Site differences in $P$. marinus prevalence and intensity, although not directly compared, were apparent. Regent Point was characterized as a site of higher disease exposure, because prevalence and intensity of $P$. marinus occurred earlier and at higher levels than at Kinsale. High prevalence and intensity of Dermo at the end of 2000 at Regent Point may have affected the number of overwintering infections and subsequent infection rates in 2001. Overwintering infections generally decrease with decreasing temperature and salinity (Ragone-Calvo \& Burreson 1994). Evidence of a winter decline in prevalence was seen at Port Kinsale, but not at Regent Point, where prevalences remained high (70\%) during the spring. Salinity was lower at Port Kinsale (8-12 ppt) than at Regent Point (15 ppt) during the early spring (March and April, 2001), and may have contributed to differences in prevalence. The high prevalence at Regent Point suggests that individuals retained high infections over the winter to initiate transmission of $P$. marinus when environmental conditions were favorable for development of the parasite. At Port Kinsale, prevalences and intensities of $P$. marinus infections were lower than at Regent Point in the spring, suggesting a lower number of overwintering infections. However, frequency distribution of infection intensities from May 2001 indicates that there were individuals with high infection intensities at Port Kinsale (Fig. 12). Such individuals may be responsible for initiating an epizootic, even when mean infection levels are low (Ford et al. 1999).

The presence of MSX disease also may explain differences in mortality between sites. MSX was initially detected in September 2000 at Regent Point and in the summer months of 2001, but was not detected at Port Kinsale throughout the study. Overall cumulative mortalities were higher at Regent Point than at Port Kinsale. Mortalities in the LOB stock were higher at Regent Point and similar to the CRB stock. MSX does not occur in the Gulf of Mexico therefore, the LOB stock would have had no resistance to H. nelsoni. Response to selection for resistance to $H$. nelsoni is apparently high, and can be attained in 1-2 generations (Ford \& Haskin 1987). It would be expected that MSX resistance could be readily accomplished in Louisiana stocks through selective breeding. As demonstrated in existing Delaware Bay (DEBY)

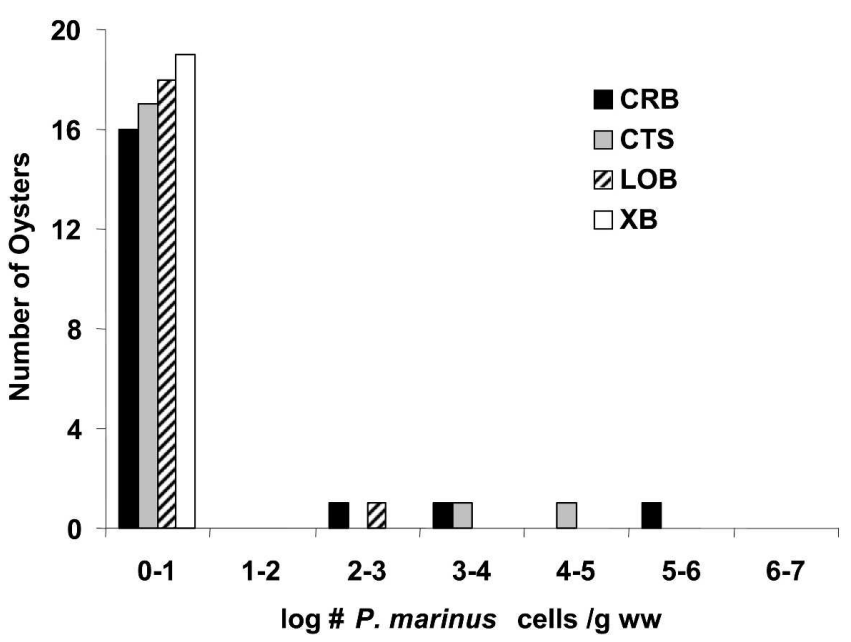

Figure 12. Frequency distribution of infection intensities of $P$. marinus during May, 2001 at Port Kinsale. Distribution of infection intensities among the CRB, CTS, LOB, and XB oysters illustrate the presence of individuals with high intensities of infection during a period when mean infection intensities are low. CRB = Chesapeake Bay, Rappahannock River, CTS = Chesapeake Bay, Tangier Sound, LOB = Louisiana, Oyster Bayou, XB = CROSBreed strain. 
strains, dual resistance to Dermo and MSX can be achieved over several generations (Ragone-Calvo et al. 2003).

\section{Growth}

In addition to increased survival, it was expected that diseaseresistant stocks would exhibit improved growth because they would be better able to withstand the chronic effects of disease. Oyster strains that were MSX-resistant displayed an energetic advantage over susceptible strains (Barber et al. 1991a). The CRB stock, although highly susceptible to disease, reached market size (75-mm shell height) earlier than the other stocks. At Regent Point the CRB oysters reached market size in August 2000 at Regent Point and in November 2000 at Port Kinsale, before infection intensities became lethal. Comparisons of time to market size and cumulative mortalities at market size show that the CRB stock reached market size the fastest, and had the lowest mortalities at the time market size was attained (Fig. 13A, 13B). The rapid growth of the CRB stock indicates that this stock may be a useful aquaculture strain, particularly in areas where MSX intensities are low or absent. Fast growing oyster strains can be used to avoid the effects of Dermo disease, even in strains with no developed resistance to P. marinus (Allen et al. 1993). Disease resistance in this stock may also be improved through further selection, as has been the case with some MSX-resistant strains, which now grow faster than unselected strains (Matthiessen et al. 1990, Ragone-Calvo et al. 2003).

Dry weights declined in June 2001, whereas shell heights continued to increase, making growth comparisons difficult. In the present study we used shell height and dry weight as indices of overall growth. From a practical perspective, shell height is the most convenient method to compare performance among oyster strains. Determination of market size in the Gulf of Mexico and the Chesapeake Bay is based on shell height and so remains an important metric to oyster culturists in those areas. Additionally, despite the seasonal decrease in dry weight, log mean dry weights among all stocks correlated strongly with log mean shell heights at both sites from deployment to the end of the experiment (Fig. 14).

\section{Condition Index}

Demonstration of sublethal effects of disease on condition and energy reserves that can be ascribed to differences in disease resistance, remain equivocal. Differences in condition did not reflect patterns of survival (and presumably disease resistance), as condition index was highest in both resistant (XB) and susceptible (CRB) stocks (Fig. 8). In previous studies, condition index was reduced by $P$. marinus infection (Craig et al. 1989, Crosby \& Roberts 1990, Paynter \& Burreson 1991). However, high sitespecific variation, attributed to differences in salinity, made it difficult to distinguish among several Gulf coast sites (Craig et al. 1989). Although statistically significant, intensity of infection explained less than $10 \%$ of the variablility in condition index in South Carolina oyster populations (Crosby \& Roberts 1990). Paynter and Burreson (1991) compared the condition index between infected and uninfected oysters, not the relationship between intensity of infection and condition index. In their study, condition indices remained high during the months of increasing Dermo infections, in contrast to the present study.

In the present study, environmental influences (e.g., changes in temperature and food availability) on condition were likely greater than effects of disease. Seasonal variation in oyster condition exhibits remarkable inter-annual and intra-river consistency in the Chesapeake Bay (Austin et al. 1993). This may be related to consistency in the timing of phytoplankton blooms and food availability (Deslous-Paoli \& Heral 1988). Because seasonal variation in condition index can be consistent from year to year, identifying effects of disease on condition may be difficult or unique to specific regions within the Chesapeake Bay.

Sublethal effects of Dermo disease may be important at critical periods of the eastern oyster's reproductive cycle. Condition and gonadal indices decreased with infection during periods prior to
A.

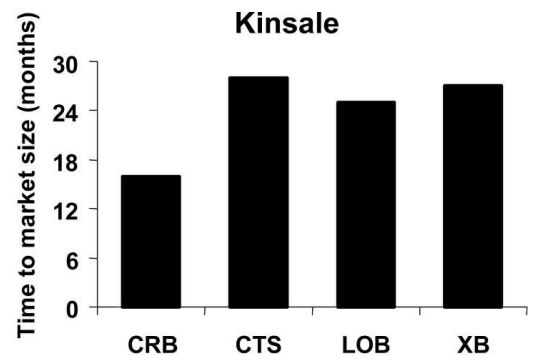

B.

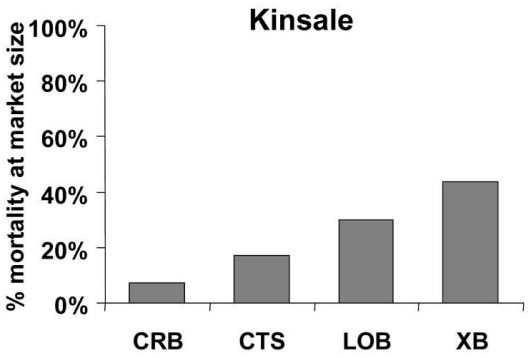

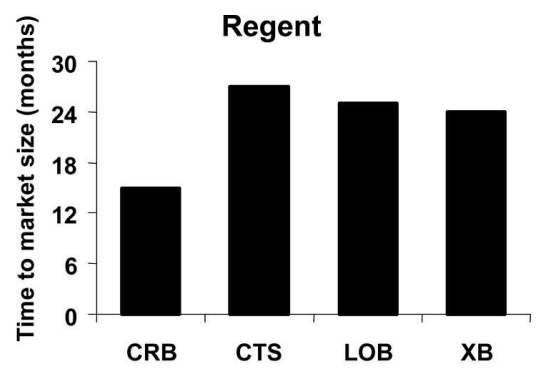

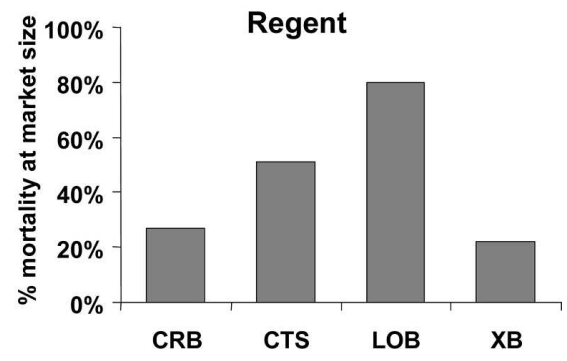

Figure 13. A. Months to market size among natural oyster stocks (CRB, CTS, LOB) and one hatchery strain (XB) at Port Kinsale and Regent Point. B. Cumulative mortalities $(\%)$ of oyster stocks at market size $(75 \mathrm{~mm})$ at Port Kinsale and Regent Point. CRB = Chesapeake Bay, Rappahannock River, CTS = Chesapeake Bay, Tangier Sound, LOB = Louisiana, Oyster Bayou, XB = CROSBreed strain. 


\section{Kinsale}

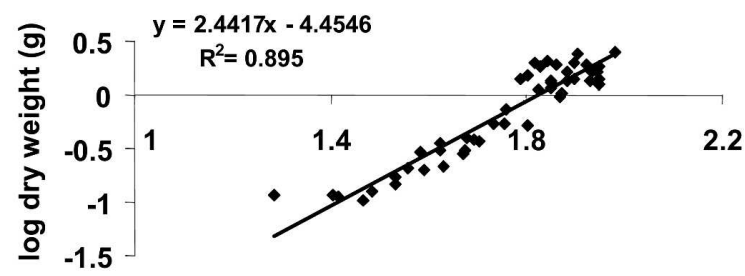

B.
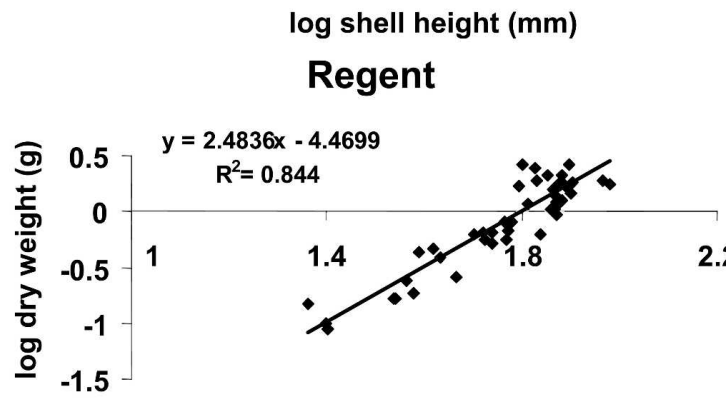

log shell height $(\mathrm{mm})$

Figure 14. Comparisons of $\log$ shell height $(\mathrm{mm})$ and $\log$ dry weight (g) at A. Port Kinsale and B. Regent Point. Shell height and dry weight data are the $\log$ of mean shell height and dry weight at each period sampled. The means are collapsed across oyster stocks. CRB = Chesapeake Bay, Rappahannock River, CTS = Chesapeake Bay, Tangier Sound, LOB = Louisiana, Oyster Bayou, XB = CROSBreed strain.

and during gametogenesis (Dittman et al. 2001). These relationships may be a reflection of prior exposure to Perkinsus, as negative effects on condition were only seen during periods when the parasite would be expected to be quiescent (winter to early spring). Their study implies that increased parasite loads hinder the ability of the oyster to undergo reproductive maturation. In the present study, effects of disease on condition may be more relevant during similar periods (late fall-winter and early spring) when condition index is high. During periods of low condition (summer, presumably post spawning) effects are not discernible because seasonal effects on condition mask any effects of disease. Spawning periods in the Virginia portion of the Chesapeake Bay are typically from June to September, with two spawning periods in the summer and fall (Andrews 1979, Hayes \& Menzel 1981). A critical period may be during maturation prior to the second spawning in the fall, when oysters are still heavily infected. During this period, increases in dry weight were seen in the XB and LOB stocks at Kinsale, implying that these stocks were able to recover from the dual stresses of spawning and disease.

Despite the difficulty in detecting effects of $P$. marinus on physiologic condition, the observation that condition index varies among stocks grown under a common environment has important implications for aquaculture. Condition index is used as an indicator of meat quality (Lucas \& Beninger 1985). Indicators of condition may be important criteria, along with growth and survival, in choosing a suitable strain for grow out. Stocks showed significant differences in condition. These differences were most significant at specific months. If these differences are consistent over successive growth seasons, then months when condition is highest may be targeted as optimal harvest periods, a typical practice of oyster growers (Brown and Hartwick 1988). Consistent differences in condition among stocks or strains may be useful indicators of performance and criteria for selective breeding. Growth and reproductive patterns of genetically distinct eastern oyster strains can remain fixed over multiple generations (Loosanoff 1969, Barber et al. 1991b, Dittman et al. 1998), improving the predictability of optimizing strain selection. Condition index alone, however, may not be solely indicative of meat quality. In the first year of growth, condition index of all stocks decreased during the summer and was attributed to increases in shell weight, as dry weights continued to increase during this period. At Kinsale, condition index was comparatively low in the LOB stock, but their dry weights were highest among all stocks. It was more likely that changes in condition index of the LOB stock reflected differences in shell weight, because all Louisiana oysters grown at Kinsale developed noticeably thicker shells.

\section{Energy Reserves}

Glycogen and TAG values decreased during the summer months in a similar manner to the condition index, suggesting mobilization of nutrient reserves during gametogenesis and spawning (Engle 1951, Trider \& Castell 1980). Seasonal influences on energy reserves may have masked effects of disease. Infection by H. nelsoni reduced condition index and energy reserves in C. virginica (Barber et al. 1988a, Barber et al. 1988b). In earlier studies, effects of $P$. marinus on biochemical composition were variable. Stein and Mackin (1957) showed in histochemical assays that glycogen was depleted in infected oysters. Glycogen, however, was higher in infected oysters than in uninfected oysters in studies by Wilson et al. (1988) and White et al. (1988). In these studies oysters were also parasitized by the snail, Boonea impressa, so glycogen levels may have been affected by this parasite as well. In Galveston Bay, glycogen concentrations were negatively correlated with infections that were greater than light (Soniat et al. 1989). Glycogen, however, also decreased with salinity, so environmental effects on glycogen could not be ruled out. Increases in lipid phosphate and fatty acids were observed in $P$. marinus infected oysters (Wilson et al. 1988), but no other recent studies, besides this one, have examined effects of Dermo disease on lipid content of the oyster. In the present study, effects of $P$. marinus on TAG were not apparent. As with glycogen, seasonal variation in TAG may make it difficult to detect any effects $P$. marinus might have on lipid stores. Individual variation in TAG and glycogen was also high. Perkinsus marinus was demonstrated to reduce reproductive output and gametogenic development (Kennedy et al. 1995, Dittman et al. 2001). Demonstration of other physiological effects has been less clear. Oxygen consumption in oysters was not reduced by Dermo infection (Newell et al. 1994, Willson \& Burnett 2000). Seasonal cycles in energy reserves strongly influence the physiological state of disease resistant and susceptible oysters and must be taken into account when examining effects of disease in the field. As shown by Dittman et al. (2001), specific periods related to gametogenic phases of the oyster may be when effects of disease are most crucial. Processes of nutrient assimilation and storage must be examined in the context of these periods to determine the physiological effects of Dermo disease.

This study is the first field test demonstrating variation in Dermo-resistance of native stocks within (Chesapeake Bay-CRB and CTS) and between (Gulf of Mexico vs. Chesapeake Bay) 
regions. We identified a native stock possessing resistance to $P$. marinus. The identification of the CTS stock as Dermo-resistant may be an important step in developing new disease-resistant hatchery strains. Furthermore, the CTS stock seems to be more resistant to MSX than the other stocks tested. The development of disease-resistant strains is a paramount objective in the Chesapeake Bay, for providing seed for oyster reef restoration and for developing commercial aquaculture. In addition to survival and disease resistance, performance related traits such as growth and condition must be considered when selecting suitable strains for aquaculture because parameters related to disease resistance and performance are not necessarily correlated.

\section{ACKNOWLEDGMENTS}

We thank members of the Chu and Allen labs for assistance in field and lab sampling; members of Dr. Eugene M. Burreson's lab for assistance with MSX diagnosis; personnel at the VIMS-ABC hatchery for assistance in broodstock conditioning, spawning, larval care, and nursery of oysters; and special thanks to Drs. Jeff Shields, Sandy Shumway, and Bob Diaz for constructive reviews of earlier drafts of this manuscript. This research was supported by the NOAA-Sea Grant Oyster Disease Research Program (Project \# VA-OD-99-3). Contribution no. 2645 from the Virginia Institute of Marine Science, College of William and Mary.

\section{LITERATURE CITED}

Allen, S. K., Jr., R. S. Anderson, L. L. Brubacher, L. M. Mora, K. T. Paynter, E. M. Burreson, B. J. Barber, R. Mann, D. C. Brown. 1993. Oyster Disease Research (ODR) Program. J. Shellfish Res. 12(2):351-368.

Andrews, J. D. 1954. Notes on fungus parasites of bivalve mollusks in Chesapeake Bay. Proc. Natl. Shellfish. Assoc. 45:157-163.

Andrews, J. D. \& W. F. Hewatt. 1957. Oyster mortality studies in Virginia. II. The fungus disease caused by Dermocystidium marinum in oysters in Chesapeake Bay. Ecol. Monogr. 27:1-26.

Andrews, J. D. 1979. Oyster diseases in the Chesapeake Bay. Mar. Fish. Rev. 41(1-2):45-53.

Andrews, J. D. \& S. M. Ray. 1988. Management strategies to control the disease caused by Perkinsus marinus. In: W. S. Fisher, editor. Disease processes in marine bivalve molluscs. Bethesda, Maryland: Am. Fish. Soc., Spec. Publ. 18. pp. 257-264.

Austin, H., D. S. Haven \& M. S. Moustafa. 1993. The relationship between trends in a condition index of the American oyster, Crassostrea virginica, and environmental parameters in three Virginia estuaries. Estuaries 18(2):362-374.

Barber, B. J., S. E. Ford \& H. H. Haskin. 1988a. Effects of the parasite MSX (Haplosporidium nelsoni) on oyster (Crassostrea virginica) energy metabolism. I. Condition index and relative fecundity. J. Shellfish Res. 7:25-31.

Barber, B. J., S. E. Ford \& H. H. Haskin. 1988b. Effects of the parasite MSX (Haplosporidium nelsoni) on oyster (Crassostrea virginica) energy metabolism. II. Tissue biochemical composition. Comp. Biochem. Physiol. 91A:603-608.

Barber, B. J., S. E. Ford \& D. T. J. Littlewood. 1991a. A physiological comparison of resistant and susceptible oysters Crassostrea virginica (Gmelin) exposed to the endoparasite Haplosporidium nelsoni (Haskin, Stauber \& Mackin). J. Exp. Mar. Biol. Ecol. 146:101-112.

Barber, B. J., S. E. Ford \& R. N. Wargo. 1991b. Genetic variation in the timing of gonadal maturation and spawning of the eastern oyster, Crassostrea virginica. Biol. Bull. 181:216-221.

Blankenship, K. 1997. Oyster rescued from VA harvest may return favor. Chesapeake Bay Journal 7:9.

Bligh, E. G. \& W. J. Dyer. 1959. A rapid method of total lipid extraction and purification. Canadian. J. Biochem. Physiol. 37(3):911-917.

Brown, J. R. \& E. B. Hartwick. 1988. Influences of temperature, salinity and available food upon suspended culture of the Pacific oyster, Crassostrea gigas. II. Condition index and survival. Aquaculture 70:253267.

Burreson, E. M. 1991. Effects of Perkinsus marinus infection in the eastern oyster, Crassostrea virginica. I. Susceptibility of native and MSXresistant stocks. J. Shellfish Res. 10:417-423.

Burreson, E. M., M. E. Robinson \& A. Villalba. 1988. A comparison of paraffin histology and hemolymph analysis for the diagnosis of Haplosporidium nelsoni (MSX) in Crassostrea virginica (Gmelin). J. Shellfish Res. 7:19-23.

Bushek, D. \& S. K. Allen, Jr. 1996. Host-parasite interactions among broadly distributed populations of the eastern oyster Crassostrea vir- ginica, and the protozoan Perkinsus marinus. Mar. Ecol. Prog. Ser. 139:127-141.

Bushek, D., S. E. Ford \& S. K. Allen. 1994. Evaluation of methods using Ray's fluid thioglycollate medium for diagnosis of Perkinsus marinus infection in the eastern oyster, Crassostrea virginica. Ann. Rev. Fish Diseases 4:201-217.

Chesapeake Bay Journal. 1997. Oysters rescued from Virginia harvest may return favor.7:9.

Chu, F. L. \& E. S. Ozkizilcik. 1995. Lipid and fatty acid composition of striped bass (Morone saxatilis) larvae during development. Comp. Biochem. Physiol. 111B:665-674.

Choi, K. S., E. A. Wilson, D. H. Lewis, E. N. Powell \& S. M. Ray. 1989. The energetic cost of Perkinsus marinus parasitism in oysters: quantification of the thioglycollate method. J. Shellfish Res. 8:125-136.

Craig, A., E. N. Powell, R. R. Fay \& J. M. Brooks. 1989. Distribution of Perkinsus marinus in Gulf Coast oyster populations. Estuaries 12:8291.

Crosby, M. P. \& L. D. Gale. 1990. A review and evaluation of bivalve condition index methodologies with a suggested standard method. $J$. Shellfish Res. 9(1):233-237.

Crosby, M. P. \& C. F. Roberts. 1990. Seasonal infection intensity cycle of the parasite Perkinsus marinus (and an absence of Haplosporidium spp.) in oysters from a South Carolina salt marsh. Dis. Aquat. Org. 9:149-155.

Deslous-Paoli, J. M. \& M. Heral. 1988. Biochemical composition and energy value of Crassostrea gigas (Thunberg) cultured in the bay of Marennes-Oleron. Aquatic Living Resources 1:239-249.

Dittman, D. E., S. E. Ford \& H. H. Haskin. 1998. Growth patterns in oysters, Crassostrea virginica, from different estuaries. Mar. Biol. 132: 461-469.

Dittman, D. E., S. E. Ford \& D. K. Padilla. 2001. Effects of Perkinsus marinus on reproduction of the eastern oyster Crassostrea virginica, depend on timing. J. Shellfish Res. 20(3):1025-1034.

Encomio, V. G. 2004. A study of the eastern oyster, Crassostrea virginica: 1. Dermo tolerance, survival, growth condition, and Hsp 70 expression in different geographic stocks; 2. Heat tolerance and effects of sublethal heat shock on survival and Hsp70 expression of infected and uninfected oysters. Ph.D. Dissertation. College of William and Mary. 173 pp.

Encomio, V. G. \& F.-L. E. Chu. 2005. Seasonal variation in heat shock protein (hsp70) in the eastern oyster Crassostrea virginica infected with Perkinsus marinus. J. Shellfish Res. 24:167-175.

Engle, J. B. 1951. The condition of oysters as measured by the carbohydrate cycle, the condition factor and the percent dry weight. Proceedings of the National Shellfisheries Association 41:20-25.

Ford, S. E. 1988. Host-parasite interactions in oysters Crassostrea virginica, selected for resistance to Haplosporidium nelsoni (MSX): survival mechanisms against a natural pathogen. In: W. S. Fisher, editor. Disease processes in marine bivalve molluscs. Am. Fish. Soc. Spec. Publ. 18. Bethesda, MD. pp. 206-224.

Ford, S. E. \& H. H. Haskin. 1987. Infection and mortality patterns in 
strains of oysters Crassostrea virginica selected for resistance to the parasite Haplosporidium nelsoni (MSX). J. Parasitol. 73:368-376.

Ford, S. E., R. N. Wargo \& L. M. Ragone. 1988. Metabolic condition and infection levels preceding death in oysters exposed to Haplosporidium nelsoni (MSX) with an hypothesis about cause of death. In: Abstracts of 3rd International Colloquium of Pathology in Marine Aquaculture. Gloucester Point, Virginia. pp. 41-42.

Ford, S. E., A. Schotthoefer \& C. Spruck. 1999. In vivo dynamics of the microparasite Perkinsus marinus during progression and regression of infections of eastern oysters. J. Parasitol. 85(2):273-282.

Ford, S. E. \& M. R. Tripp. 1996. Diseases and defense mechanisms. In: V. S. Kennedy, R. I. E. Newell \& A. F. Eble, editors. The Eastern oyster. College Park, MD: Maryland Sea Grant College Program, Univ. of Maryland. pp. 581-660.

Gaffney, P. M. \& D. Bushek. 1996. Genetic aspects of disease resistance in oysters. J. Shellfish Res. 15(1):135-140.

Gauthier, J. D., T. M. Soniat \& J. S. Rogers. 1990. A parasitological survey of oysters along the Louisiana coast in relation to salinity. J. World Aquaculture Soc. 21:168-200.

Haskin, H. H. \& S. E. Ford. 1979. Development of resistance to Minchinia nelsoni (MSX) mortality in laboratory-reared and native oyster stocks in Delaware Bay. Mar. Fish. Rev. 41:54-63.

Hayes, P. F. \& R. W. Menzel. 1981. The reproductive cycle of early setting Crassostrea virginica (Gmelin) in the northern Gulf of Mexico, and its implications for population recruitment. Biol. Bull. 160:80-88.

Kennedy, V. S., R. I. E. Newell, G. E. Krantz \& S. Otto. 1995. Reproductive capacity of the eastern oyster Crassostrea virginica infected with the parasite Perkinsus marinus. Dis. Aquat. Org. 23:135-144.

Kennedy, V. S. 1996. The ecological role of the eastern oyster, Crassostrea virginica, with remarks on disease. J. Shellfish Res. 15(1):177-183.

La Peyre, J. F., D. Y. Shaffhauser, E. M. Rizkalla \& M. Faisal. 1995. Production of serine proteases by the oyster pathogen Perkinsus marinus (Apicomplexa) in vitro. J. Eukaryot. Microbiol. 42:451-458.

Loosanoff, V. L. 1969. Maturation of gonads of oysters, Crassostrea virginica, of different geographical areas subjected to relatively low temperatures. Veliger 11:153-163.

Lowry, O. H., N. J. Rosebrough, A. L. Farr \& R. J. Raudall. 1951. Protein measurement with Folin phenol reagent. J. Chem. 196:265-275.

Lucas, A. \& P. G. Beninger. 1985. The use of physiological condition index in marine bivalve aquaculture. Aquaculture 44:187-200.

Luckenbach, M. W., F. X. O’Beirn \& J. Taylor. 1997. An introduction to culturing oysters in Virginia. School of Marine Science, Virginia Institute of Marine Science, The College of William and Mary. Gloucester Point, Virginia. 24 pp.

Mackin, J. G. \& A. K. Sparks. 1962. A study of the effect on oysters of crude oil loss from a wild well. Publ. Inst. Mar. Sci. Univ. Texas 7:230-261.

Matthiessen, G. C., S. Y. Feng \& L. Leibovitz. 1990. Patterns of MSX (Haplosporidium nelsoni) infection and subsequent mortality in resistant and susceptible strains of the eastern oyster, Crassostrea virginica (Gmelin, 1791), in New England. J. Shellfish Res. 9(2):359-365.

Naciri-Graven, Y., A.-G. Martin, J.-P. Baud, T. Renault \& A. Gerard. 1998. Selecting the flat oyster Ostrea edulis (L.) for survival when infected with the parasite Bonamia ostreae. J. Exp. Mar. Biol. Ecol. 224:91-107.

Newell, R. I. E. 1985. Physiological effects of the MSX parasite Haplosporidium nelsoni (Haskin, Stauber, and Mackin) on the American oyster, Crassostrea virginica. J. Shellfish Res. 5:91-96.

Newell, R. I. E., K. T. Paynter \& E. M. Burreson. 1994. Physiological effects of protozoan parasitism on the eastern oyster Crassostrea virginica: feeding and metabolism. J. Shellfish Res. 13:294.

Nickens, A. D., J. F. LaPeyre, E. S. Wagner \& T. R. Tiersch. 2002. An improved procedure to count Perkinsus marinus in Eastern oyster hemolymph. J. Shellfish Res. 21(2):725-732.

Oliver, J. L., T. D. Lewis, M. Faisal \& S. L. Kaattari. 1999. Analysis of the effects of Perkinsus marinus proteases on plasma proteins of the Eastern oyster (Crassostrea virginica) and the Pacific oyster (Crassostrea gigas). J. Invertebr. Pathol. 74:173-183.

Paynter, K. T. \& E. M. Burreson, Jr. 1991. Effects of Perkinsus marinus infection in the eastern oyster, Crassostrea virginica: II. Disease development and impact on growth rate at different salinities. J. Shellfish Res. 10:425-431.

Ragone-Calvo, L. M. \& E. M. Burreson. 1994. Characterization of overwintering infections of Perkinsus marinus (Apicomplexa) in Chesapeake Bay oysters. J. Shellfish Res. 13:123-130.

Ragone-Calvo, L. M., G. W. Calvo \& E. M. Burreson. 2003. Dual disease resistance in a selectively bred eastern oyster, Crassostrea virginica, strain tested in Chesapeake Bay. Aquaculture 220:69-87.

Rainer, J. S. \& R. Mann. 1992. A comparison of methods for calculating condition index in eastern oysters, Crassostrea virginica (Gmelin, 1791). J. Shellfish Res. 11(1):55-58.

Ray, S. M. 1954. Biological studies of Dermocystidium marinum. The Rice Institute Pamphlet, special issue. 114 pp.

SAS Institute, Inc. 1999. Statistical Analysis System (SAS) Proprietary Software Version 8. Cary, NC.

Soniat, T. M., L. E. Smith \& M. S. Brody. 1989. Mortality and condition of the American oyster in Galveston Bay, Texas. Contrib. Mar. Sci. 31: 77-94.

Stein, J. E. \& J. G. Mackin. 1957. A histochemical study of the glycogen content of oysters infected by Dermocystidium marinum. Texas A\&M Research Foundation Project 23. Technical Report 20. College Station, Texas. 5 pp.

Stickler, S. M. 2004. Natural Dermo resistance and related defense mechanisms in Eastern oysters, Crassostrea virginica, with implications for restoration. Ph.D. Dissertation. The College of William and Mary. 201 pp.

Trider, D. J. \& J. D. Castell. 1980. Influence of neutral lipid on seasonal variation of total lipid in oysters, Crassostrea virginica. Proc. Natl. Shellfish. Assoc 70:112-118.

Underwood, A. J. 1997. Experiments in ecology. Cambridge, UK: Cambridge University Press. 504 pp.

Valiulis, G. A. 1973. Comparison of the resistance to Labirynthomyxa marina with resistance to Minchinia nelsoni in Crassostrea virginica. Ph.D. Dissertation. Rutgers University, New Brunswick, New Jersey.

Van Handel, E. 1965. Estimation of glycogen in small amounts of tissue. Anal. Biochem. 11:256-265.

Walne, P. R. \& R. Mann. 1975. Growth and biochemical composition in Ostrea edulis and Crassostrea gigas. In: H. Barnes, editor. Proceedings of the 9th European Marine Biology Symposium. Aberdeen University Press. pp. 587-607.

White, M. E., E. N. Powell \& S. M. Ray. 1988. Effect of parasitism by the pyramidellid gastropod Boonea impressa on the net productivity of oysters (Crassostrea virginica). Estuar. Coast. Shelf Sci. 26:359-377.

Willson, L. L. \& L. E. Burnett. 2000. Whole animal and gill tissue oxygen uptake in the eastern oyster, Crassostrea virginica: effects of hypoxid, hypercapnia, air exposure and infection with the protozoan parasite Perkinsus marinus. J. Exp. Mar. Biol. Ecol. 246:223-240.

Wilson, E. A., E. N. Powell \& S. M. Ray. 1988. The effect of the ectoparasitic pyramellid snail, Boonea impressa, on the growth and health of oysters, Crassostrea virginica, under field conditions. Fish. Bull. 86(3):553-565.

Zar, J. H. 1996. Biostatistical analysis, 4th ed. Upper Saddle River, New Jersey: Simon and Schuster. 918 pp. 